\title{
Detection of Coronatine in Halo Blight Lesions of Italian Ryegrass
}

\author{
Koushi NishiYama*, Ryutaro SAKaI*, Akinori EzUKA*, \\ Akitami Ichinara**, Kunio ShiraISHI** and Sadao SaKamUra** \\ 西山幸司・酒井隆太郎・江塚昭典・市原耿民・白石久二雄・坂村貞雄： \\ かさ枯病罹病イタリアンライグラスからのコロナチンの検出
}

Coronatine $^{1)}$ is a physiologically active substance produced by Pseudomonas coronafaciens var. atropurpurea (Reddy and Godkin) Stapp, the causal bacterium of halo blight of Italian ryegrass (Lolium multiflorum Lam. ) ${ }^{2)}$. This substance is characterized by its activity of inducing hypertrophic growth of potato tuber tissue $^{3)}$. It was isolated from the culture filtrate of the bacterium ${ }^{1)}$, and was found to induce phytotoxic lesions on the leaves of Italian ryegrass similar to the disease symptom caused by the bacterium ${ }^{4)}$. In this study, experiment was conducted to detect coronatine in diseased leaves of Italian ryegrass infected with the bacterium.

The isolate N090-1 of the causal bacterium was shake-cultured in Woolley's liquid medium ${ }^{5}$, which was used previously for isolating coronatine, for $24 \mathrm{hr}$ at 23 C. Bacterial cells were collected by centrifugation and rinsed twice in sterilized water to remove culture medium, then suspended in sterilized water and used for inoculation. Two- to three-month-old plants of Italian ryegrass, cultivar Mammoth A, were wounded by multi-needle prickings and then dipped in heavy suspension of the bacterial cells. Four to six days after inoculation, diseased leaves were harvested and subjected to coronatine isolation. Healthy leaves and bacterial cells of the same amount as the inoculum were also subjected to the same procedure as the check.

Extraction of coronatine from test samples was conducted by the following procedures. Plant leaves (150-380 $\mathrm{g}$ in fresh weight) were homogenized with water (15 $\mathrm{ml}$ per gram of leaves). The homogenate was filtrated through gauze, and centrifuged at 7,000 $\mathrm{rpm}$ for $5 \mathrm{~min}$. The supernatant was added with active charcoal-celite $(1: 1)$ mixture (40 g per liter), and kept overnight at room temperature. The slurry was packed in a column and washed with water, then acetone

* National Institute of Agricultural Sciences. Tokyo, Japan. 農業技術研究所

** Faculty of Agriculture, Hokkaido University. Sapporo, Japan. 北海道大学農学部

1) Ichihara, A., Shiraishi, K., Ogasawara, M., Sato, H., Sakamura, S., Nishiyama, K. and Sakai, R. (1975). Nineteenth Symposium on the Chemistry of Natural Products.

Hiroshima, Japan, Symposium Papers. pp. 263-268. 2) Tominaga, T. (1968). Ann. Phytopath. Soc. Japan $34: 242-249 . \quad 3)$ Nishiyama, K. and Tominaga, T. (1973). Ibid. $39: 236$ (Abstr.). 4) Nishiyama, K., Sakai, R., Ezuka, A., Ichihara, A., Shiraishi, K., Ogasawara, M., Sato, H. and Sakamura, S. Ibid. 42.613-614. 5) Woolley, D. W., Pringle, R. B. and Braun, A. C. (1952). J. Biol. Chem. 197:409-417. 6) Sakai, R., Nishiyama, K., Ichihara, A., Shiraishi, K., Ogasawara, M., Sato, H. and Sakamura, S.(1975). Proceedings of the Meeting of the Society for Chemical Regulation of Plant. Utsunomiya, Japan, Sept. 1975. pp. 7-8. 7) Dimond, A. E. and Waggoner, P. E. (1953). Phytopatho$\log$ y $43: 229-235$. 
was poured on the slurry. The eluate was evaporated in vacuo to remove the eluent. The residual water layer was acidified with $1 \mathrm{~N} \mathrm{HCl}$ and shaken with ethyl ether. The organic layer was concentrated in vacuo to reduce the volume and then shaken with $5 \%$ aqueous $\mathrm{NaHCO}_{3}$. The aqueous layer was acidified with $5 \mathrm{~N} \mathrm{HCl}$ and shaken with ethyl ether. The organic layer was concentrated in vacuo. The residue was filled up with acetone to make $3 \mathrm{ml}$. As the check, bacterial cells which were yielded from $600 \mathrm{ml}$ of the liquid medium by the same method as the inoculum were suspended in $100 \mathrm{ml}$ of distilled water, and added with $100 \mathrm{ml}$ of acetone. The mixture was centrifuged at $10,000 \mathrm{rpm}$ for $5 \mathrm{~min}$.

The precipitate was suspended in $100 \mathrm{ml}$ of acetone and kept overnight at room temperature and then filtrated. The filtrate was combined with the previous supernatant and the solvent was removed in vacuo. The residual water layer was treated with the same procedures as the plant materials. The experiment was repeated three times.

Coronatine in the final residue was detected by both bioassay using potato tuber tissue, and silica gel thin layer chromatography. In these tests, authentic coronatine was used as the check.

The bioassay of coronatine was performed as described previously ${ }^{6)}$. Disk of Toyo No. 2 filter paper $6 \mathrm{~mm}$ in diameter was moistened with acetone solution of the final residue (about $10 \mu \mathrm{l}$ ), and dried at room temperature. The disk was placed on a potato tuber segment $6 \mathrm{~mm}$ thick and $12 \mathrm{~mm}$ in diameter, then wetted with a drop of sterilized water. The potato tuber segment with the paper disk was kept on a moistened filter paper in a petri dish at $23 \mathrm{C}$, and examined for the hypertrophic growth induced by coronatine 5 days later. More than ten potato tuber segments were used for the bioassay of each test sample.

Thin layer chromatograph was developed with isopropyl ether-acetic acid (95:5, $\mathrm{v} / \mathrm{v})$, and then sprayed with anisaldehyde-sulfuric acid reagent. Coronatine was visualized as yellowish green spot (Rf 0.24) under a UV lamp.

Table 1. Detection of coronatine in healthy and halo blight leaves of Italian ryegrass and in bacterial cells of Pseudomonas coronafaciens var. atropurpurea

\begin{tabular}{c|c|c|c}
\hline \hline \multicolumn{1}{c}{ Method of detection } & Diseased leaves & Healthy leaves & Bacterial cells \\
\hline $\begin{array}{l}\text { Hypertrophic growth of } \\
\text { potato tuber tissue } \\
\text { Thin layer chromatography }\end{array}$ & + & - & - \\
\hline
\end{tabular}

Experiment was repeated three times. + : Coronatine was present. - : Coronatine was absent.

Coronatine was detected in the diseased leaves of Italian ryegrass infected with halo blight bacterium, while not detected in healthy leavaes and the bacterial cells used as the check (Table 1). This result suggests that coronatine was prduced in the host plant by the bacterium and/or the host plant in the course of their interaction. Considering the fact that coronatine can be isolated from culture filtrate of the bacterium ${ }^{1)}$, it was probably not produced by the host plant but by the bacterium, and was excreted from the bacterial cells in the course of their multiplication in the host plant. Thus it can be concluded that exotoxic coronatine serves as a vivotoxin ${ }^{7)}$ during pathogenesis. 